\title{
Neuroimaging in cannabis use: a systematic review of the literature
}

\author{
R. Martín-Santos ${ }^{1,2,3 *}$, A. B. Fagundo ${ }^{2,4}$, J. A. Crippa ${ }^{1,3,5}$, Z. Atakan ${ }^{1,3}$, S. Bhattacharyya ${ }^{1}$, P. Allen ${ }^{1}$, \\ P. Fusar-Poli ${ }^{1}$, S. Borgwardt ${ }^{1,6}$, M. Seal ${ }^{1,7}$, G. F. Busatto ${ }^{8}$ and P. McGuire ${ }^{1,3}$ \\ ${ }^{1}$ Section of Neuroimaging, PO67 Division of Psychological Medicine, Institute of Psychiatry, King's College London, UK \\ ${ }^{2}$ Neuropsychopharmacology Group, IMIM-Hospital del Mar and Department of Psychiatry; Institute of Neurosciences, Hospital Clinic, \\ IDIBAPS, CIBERSAM, Barcelona, Spain \\ ${ }^{3}$ INCT Translational Medicine, Brazil \\ ${ }^{4}$ Universidad Autónoma de Barcelona, Barcelona, Spain \\ ${ }^{5}$ Department of Neurosciences and Behaviour, School of Medicine of Riberão Preto, São Paulo University, Brazil \\ ${ }^{6}$ Psychiatric Out-patient Department (SJB), University Hospital Basel, Basel, Switzerland \\ ${ }^{7}$ Melbourne Neuropsychiatry Centre, The University of Melbourne, Australia \\ ${ }^{8}$ Department of Psychiatry, School of Medicine, Sao Paulo University, Brazil
}

Background. We conducted a systematic review to assess the evidence for specific effects of cannabis on brain structure and function. The review focuses on the cognitive changes associated with acute and chronic use of the drug.

Method. We reviewed literature reporting neuroimaging studies of chronic or acute cannabis use published up until January 2009. The search was conducted using Medline, EMBASE, LILACS and PsycLIT indexing services using the following key words: cannabis, marijuana, delta-9-tetrahydrocannabinol, THC, cannabidiol, CBD, neuroimaging, brain imaging, computerized tomography, CT, magnetic resonance, MRI, single photon emission tomography, SPECT, functional magnetic resonance, fMRI, positron emission tomography, PET, diffusion tensor MRI, DTI-MRI, MRS and spectroscopy.

Results. Sixty-six studies were identified, of which 41 met the inclusion criteria. Thirty-three were functional (SPECT/PET/fMRI) and eight structural (volumetric/DTI) imaging studies. The high degree of heterogeneity across studies precluded a meta-analysis. The functional studies suggest that resting global and prefrontal blood flow are lower in cannabis users than in controls. The results from the activation studies using a cognitive task are inconsistent because of the heterogeneity of the methods used. Studies of acute administration of THC or marijuana report increased resting activity and activation of the frontal and anterior cingulate cortex during cognitive tasks. Only three of the structural imaging studies found differences between users and controls.

Conclusions. Functional neuroimaging studies suggest a modulation of global and prefrontal metabolism both during the resting state and after the administration of THC/marijuana cigarettes. Minimal evidence of major effects of cannabis on brain structure has been reported.

Received 17 October 2008; Revised 5 June 2009; Accepted 10 June 2009; First published online 23 July 2009

Key words: Brain effect, cannabis, CBD, cognitive tasks, cognition, marijuana, neuroimaging, systematic review, THC.

\section{Introduction}

Marijuana (Cannabis sativa) is the world's most widely used illicit drug (Watson et al. 2000; Zuardi, 2006). The principal psychoactive constituent of cannabis is $\Delta^{9}$-tetrahydrocannabinol (THC) (Hirst et al. 1998). Other important components of the plant are cannabidiol (CBD), cannabinol (CBN) and cannabigerol

* Address for correspondence: Dr R. Martín-Santos, Department of Psychiatry, Institute of Neurosciences, Hospital Clinic, IDIBAPS, CIBERSAM, Villarroel, 170, 08036 Barcelona, Spain.

(Email : rmsantos@clinic.ub.es)
(CBG) (Williamson \& Evans, 2000). Except for CBD, cannabinoids act as agonists at specific endogenous cannabinoid receptors, $\mathrm{CB}_{1}$ and $\mathrm{CB}_{2}$ (Pertwee \& Ross, 2002). The $C B_{1}$ receptor is largely expressed in the central nervous system with the highest concentrations in the basal ganglia, prefrontal cortex, anterior cingulate cortex (ACC) and hippocampus (Pertwee \& Ross, 2002). $C_{2}$ receptors are mainly present in immune cells and peripheral tissues. CBD has weak partial antagonistic properties at the $C_{1}$ receptor. It inhibits the reuptake and hydrolysis of anandamide, and exhibits neuroprotective antioxidant activity (Roser et al. 2008). 
Cannabis intoxication is associated with a large variety of physiological and cognitive alterations (Hollister, 1986; Hall \& Solowij, 1998; Lundqvist, 2005). Moreover, use of the drug has been associated with an increased risk for the onset of schizophrenia, especially in adolescent users (Arsenault et al. 2004; DeLisi, 2008; Schneider, 2008). These effects may be related to the binding of cannabinoids to $\mathrm{CB}_{1}$ receptors (Freund et al. 2003). CBD reverses some of the biochemical, physiological and behavioural effects of $\mathrm{CB}_{1}$ receptor agonists, attenuating the anxiogenic effect of THC (Zuardi et al. 1982).

Neuroimaging has provided powerful tools to study the in vivo effects of cannabis on brain structure and function (Volkow et al. 2003; Crippa et al. 2005). These effects can be analysed in experimental settings following the administration of THC and CBD or indirectly by comparing subjects with and without a history of cannabis use. Recent reviews have examined this topic (Quickfall \& Crockford, 2006; Chang \& Chronicle, 2007; Gonzalez, 2007). However, these reviews only examined papers published up to 2005 (Quickfall \& Crockford, 2006) or 2006 (Chang \& Chronicle, 2007), and their selection criteria have not been clearly specified (Chang \& Chronicle, 2007; Gonzalez, 2007) or have not been sufficiently restrictive (Quickfall \& Crockford, 2006). In present study, we conducted a systematic review to assess the evidence for specific effects of cannabis on brain structure and function, focusing on the cognitive changes associated with chronic or acute cannabis use. Papers published up until January 2009 have been included. Given the large number of variables that might influence the results of neuroimaging studies, we established a comprehensive search strategy and restrictive set of criteria for selecting articles.

\section{Method}

\section{Search strategy}

Electronic searches were performed using EMBASE (1980-January 2009), Medline (1966-January 2009), PubMed (1966-January 2009), PsycLIT (1974-January 2009) and LILACS (1982-January 2009) databases, reference searching, and chapters in books on substance abuse neuroimaging. We used the following key words: marijuana; cannabis; delta-9-tetrahydrocannabinol, THC; cannabidiol, CBD; neuroimaging; brain imaging; computerized tomography, CT; magnetic resonance, MRI; single photon emission tomography, SPECT; functional magnetic resonance, fMRI; positron emission tomography, PET; diffusion tensor MRI, DTI-MRI; spectroscopy, MRS. We included all studies published up until January 2009 without any language restriction.

\section{Selection criteria}

Initially we performed a general review of all neuroimaging studies that investigated brain structure or function in relation to cannabis use. Studies were only included if they met the following criteria. (1) For studies with a case-control design: inclusion of a control group of healthy volunteers (participants of both groups had to be matched for age, sex and handedness; users had to be abstinent for at least $12 \mathrm{~h}$ before brain scanning). (2) For studies involving experimental administration of cannabinoids: use of a parallel design with healthy controls or cross-over design; subjects had to be abstinent for cannabinoids at least 1 week before the experiment, $24 \mathrm{~h}$ for alcohol, and no smoking of tobacco or drinking caffeine on the day of the experiment (Gorelick \& Heishman, 2006).

The exclusion criteria were: (1) non-neuroimaging studies of cannabis use; and (2) neuroimaging studies that involved participants $<18$ years of age, or subjects who had other neurological or psychiatric disorders, or individuals with substance abuse disorders who were not abstinent or who tested positive for drugs other than cannabis on urine screening.

When the data from a single subject sample were reported in separate publications, these were treated as a single study with multiple independent variables. Conversely, a publication that reported two forms of different imaging data from the same subjects (e.g. MRI and PET) or a study examining the same subjects with two different cognitive tasks (e.g. auditory attention and verbal working memory) were considered as two studies.

Finally, we defined chronic cannabis users as persons who used cannabis several times a week and who had done so for at least 2 years. Recreational (or occasional) cannabis users were defined as persons who used cannabis sporadically (less than four times a month) whereas naïve cannabis users or healthy controls were persons who had used cannabis less than 15 times in their lifetime, according to standardized strict criteria (Crippa et al. 2004).

\section{Recorded variables}

Two of the authors extracted the data independently (A. F. and R. M. S.). When there was no agreement, a third author (J. A. C.) reviewed the paper independently. The recorded variables for each article were gender, age, number of joints (cannabis cigarettes)/ week/years of use (to classify subjects as chronic, recreational or naïve cannabis users), handedness of 
subjects, type of design, exclusion criteria (for neurological, psychiatric or drug history), interval of cannabis and other drugs abstinence (as checked by urine tests), rest/active condition (for functional imaging studies), type of task performed during functional imaging, blinded design, randomization, doses of cannabis (percentage of THC of cannabis cigarettes or $\mathrm{mg} / \mathrm{mi}$, of THC intravenous administered or oral THC (in $\mathrm{mg}$ ), or oral CBD (in $\mathrm{mg}$ ), plasma concentration levels, pulse rate, respiratory rate, blood pressure and degree of intoxication. We also recorded all psychopathological variables, such as ratings of depersonalization, temporal disintegration, paranoid symptoms, anxiety or depression. For structural and functional imaging data, the primary measures of interest were global and regional volume and global and regional activity [cerebral blood flow (CBF), regional $\mathrm{CBF}$ (rCBF) or blood oxygen level dependent (BOLD) signal].

\section{Results}

Of the 66 studies identified initially, three were published in the 1970s, four in the 1980s, 12 from 1991 to 1999, and 47 between 2000 and 2008. Twenty-five studies were eliminated because they did not meet $a$ priori selection criteria (for excluded studies and reasons for exclusion, see Fig. 1). The remaining studies were grouped according to the neuroimaging technique used (structural/functional), effects of cannabis use (acute effects of $\mathrm{THC} /$ marijuana/CBD administration/chronic effects of cannabis use) and testing conditions (resting condition/cognitive task) (Fig. 1). The studies examined thus comprised: 15 studies involving experimental administration of $\mathrm{THC} /$ marijuana (nine in the resting state and six during a cognitive task), three studies involving experimental administration of CBD (one in the resting state and two during a cognitive task), eight structural imaging studies evaluating chronic effects of THC [five volumetric and three diffusion tensor imaging (DTI) studies] and 17 functional imaging studies on chronic THC effects (seven in the resting state and 10 during a cognitive task). The reviewed studies included a total number of 655 cannabis users and 402 healthy controls.

Because of the heterogeneity in the study design (case-control/parallel/cross-over) and the methods used (such as neuroimaging technique) we decided it would be impractical to perform a meta-analysis. Moreover, a systematic review without meta-analysis was chosen for several other reasons: (a) information needed to compute effect size was not always available, $(b)$ the methods and extent of detailed information to define regions of interest vary widely in the studies, preventing accurate comparison, $(c)$ there is a large difference in secondary variables across studies (i.e. gender), and (d) meta-analysis has intrinsic limitations in estimating negative findings that do not get published (the file drawer problem).

\section{Acute effects (see Table 1)}

Acute effects of cannabis on resting state activity

After smoking marijuana cigarettes. Three ${ }^{133}$ Xe-SPECT studies examined resting state CBF in chronic or recreational cannabis users before and after smoking marijuana cigarette with controlled THC dose (Table 1).

The studies included in this category described increased regional activity at rest relative to baseline or marijuana cigarette without THC. An increase in resting global CBF relative to baseline at 30-60 min following the smoking of a marijuana cigarette with THC in a proportion of $1.75 \%$ or $3.55 \%$ was reported in cannabis users 2 weeks after cessation of use (Mathew et al. 1992a, Mathew \& Wilson, 1993). Increased activity was also observed in the left temporal lobe after smoking a marijuana cigarette with $2.2 \%$ of THC (Mathew et al. 1989).

Subjective levels of intoxication (Mathew et al. 1992a, Mathew \& Wilson, 1993), dissociative experiences [Temporal Disintegration Inventory (TDI)], measures of depersonalization [Depersonalization Inventory (DPI); Mathew \& Wilson, 1993)] and measures of confusion (Mathew \& Wilson, 1993) have been correlated with increased global CBF after marijuana smoking. Anxiety and confusion in chronic users following marijuana smoking have been inversely correlated with regional activity in several brain areas after controlling for multiple comparisons (Mathew et al. 1989). The heart rate correlated positively with changes in global CBF following the smoking of a marijuana cigarette (Mathew et al. 1992a) and inversely with $\mathrm{rCBF}$ in the right frontal, bilateral temporal, parietal and occipital cortices (Mathew et al. 1989). Increased global CBF has also been correlated with plasma THC levels (Mathew et al. 1992a).

After THC administration. Six studies examined resting state $\mathrm{CBF}$ and metabolism in chronic or recreational cannabis users before and after the experimental administration of THC. Four of these studies used ${ }^{15} \mathrm{OH}_{2} \mathrm{O}-\mathrm{PET}$ (Mathew et al. 1997, 1998, 1999, 2002), one used ${ }^{18} \mathrm{~F}$-fludeoxyglucose (FDG)-PET (Volkow et al. 1996) and one used $\left[{ }^{11} \mathrm{C}\right]$ raclopride-PET (Bossong et al. 2009). All but the Volkow et al. study (1996) were controlled with placebo (Table 1).

All of these studies described increased regional activity at rest relative to baseline or placebo following 


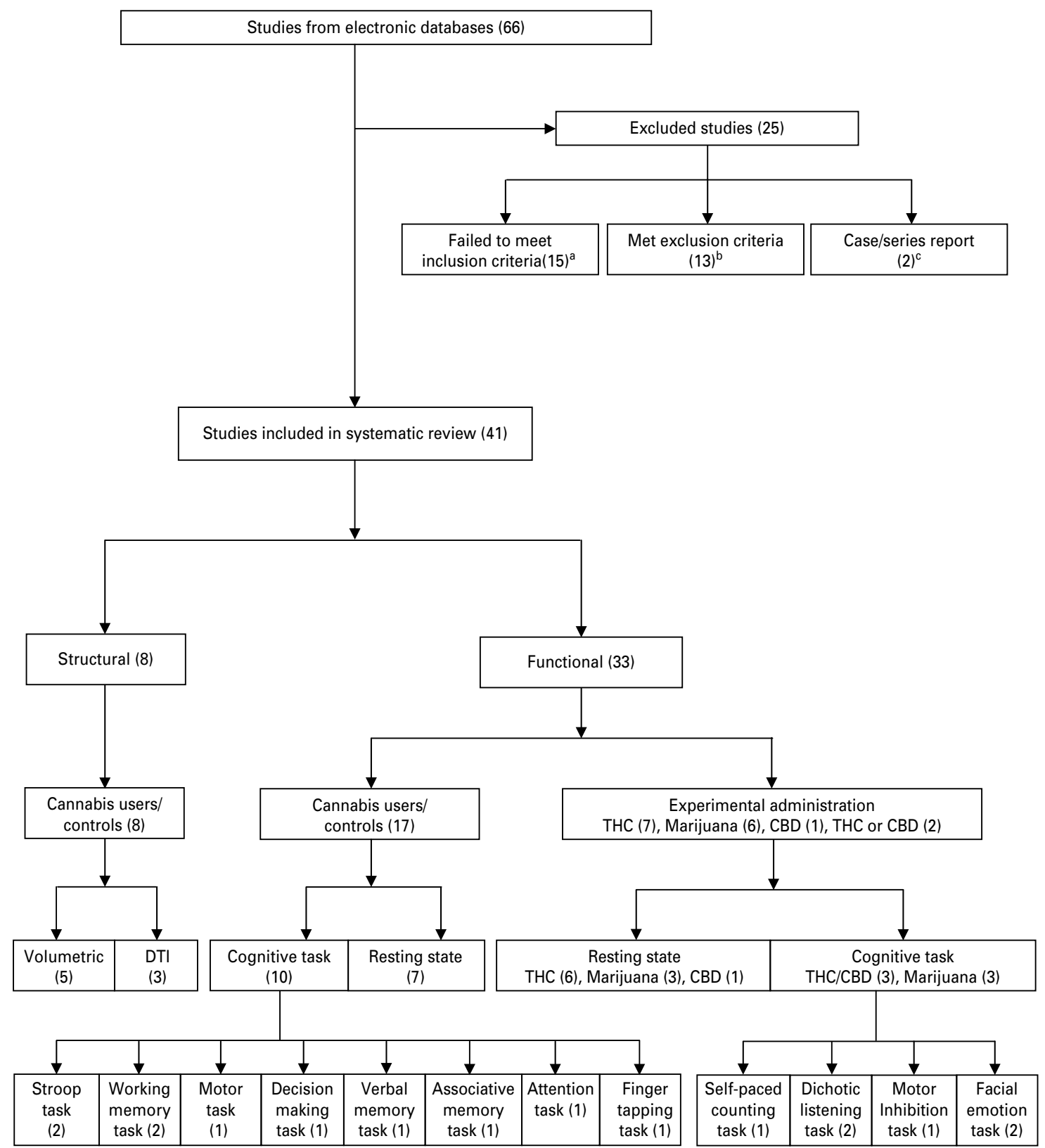

Fig. 1. Flow diagram (selection strategy) of included studies. ${ }^{a}$ No age, sex or handedness matched: Campbell et al. 1971 ; Co et al. 1977; Kuehnle et al. 1977; Hannerz \& Hinmarsh, 1983; Aasly et al. 1993; Amen \& Waugh, 1998; Yurgelun-Todd et al. 1998; O'Leary et al. 2000; Ward et al. 2002; Jacobsen et al. 2004; Sneider et al. 2006. No cannabis abstinence: Wiesbeck \& Taeschner, 1991 ; Aasly et al. 1993; O'Leary et al. 2000; Vorunganti et al. 2001; Hermann et al. 2007; Nestor et al. 2008; Weinstein et al. 2008. b Psychiatric, other abuse or medical disorders: Campbell et al. 1971; Wiesbeck \& Taeschner, 1991; Yurgelun-Todd et al. 1998; Vorunganti et al. 2001; Ward et al. 2002; Li et al. 2005; Schweinsburg et al. 2005; Voytek et al. 2005; Jacobsen et al. 2007; Ashtari et al. 2009. No healthy controls: Wiesbeck \& Taeschner, 1991; Wilson et al. 2000. Others: Volkow et al. 1991; Mathew et al.

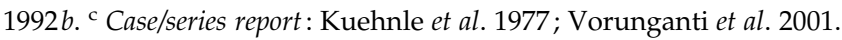

administration of THC. An increase in resting global CBF relative to baseline at $30-60 \mathrm{~min}$ following THC administration was reported in cannabis users 2 weeks after cessation of use (Mathew et al. 1997). Increased activity was also described in the ACC (Mathew et al. 1997, 1998, 1999, 2002), the insula (Mathew et al. 1997,
1998, 1999, 2002), the prefrontal and orbitofrontal cortices (Volkow et al. 1996) and the cerebellum (Mathew et al. 1998, 2002). Findings in the basal ganglia, thalamus, amygdala and hippocampus have been inconsistent, with reports of both increased and reduced activity in these areas after administration of THC in 
Table 1. Acute effects of cannabis use: functional studies (resting state or with a cognitive task)

\begin{tabular}{|c|c|c|c|c|c|c|c|c|c|c|c|}
\hline Author & Method & $\begin{array}{l}\text { Users/ } \\
\text { controls }\end{array}$ & $\begin{array}{l}\text { Mean age } \\
\text { (S.D.) users / } \\
\text { controls }\end{array}$ & $\begin{array}{l}\text { Users' } \\
\text { type }\end{array}$ & THC dose $\mathrm{a}^{\mathrm{a}}$ & $\begin{array}{l}\mathrm{THC} \\
\text { route }\end{array}$ & $\begin{array}{l}\text { Comparison } \\
\text { placebo/ } \\
\text { baseline }\end{array}$ & $\begin{array}{l}\text { Image } \\
\text { analysis }\end{array}$ & Condition & $\begin{array}{l}\text { Greater volume/ } \\
\text { resting blood flow/ } \\
\mathrm{BP}_{\mathrm{ND}} / \text { activation } \\
\text { in users }\end{array}$ & $\begin{array}{l}\text { Reduced volume/ } \\
\text { resting blood flow/ } \\
\mathrm{BP}_{\mathrm{ND}} / \text { activation } \\
\text { in users }\end{array}$ \\
\hline \multicolumn{12}{|c|}{ Functional (resting state) after marijuana cigarette } \\
\hline $\begin{array}{l}\text { Mathew et al. } \\
(1989)\end{array}$ & ${ }^{133} \mathrm{Xe}-\mathrm{SPECT}$ & $17 / 14$ & $\begin{array}{r}28.3(8.3) / \\
26.9(7.5)\end{array}$ & $\mathrm{C}$ & $2.2 \%$ & s & Baseline & $\begin{array}{l}\text { Scintillation } \\
\text { detector }\end{array}$ & Resting state & $\begin{array}{l}\mathrm{L} / \mathrm{R} \text { frontal blood flow } \\
\mathrm{L} \text { temporal blood } \\
\text { flow (chronic users) }\end{array}$ & $\begin{array}{l}\text { Baseline global CBF } \\
\text { (chronic users versus } \\
\text { recreational users) }\end{array}$ \\
\hline $\begin{array}{l}\text { Mathew et al. } \\
(1992 a)\end{array}$ & ${ }^{133} \mathrm{Xe}-\mathrm{SPECT}$ & $20 / 0$ & $25.3(6.4)$ & $\mathrm{R}$ & $1.75 \% / 3.55 \%$ & s & Placebo & $\begin{array}{l}\text { Scintillation } \\
\text { detector }\end{array}$ & Resting state & $\begin{array}{l}\mathrm{R} \text { frontal and temporal } \\
\text { blood flow } \\
\mathrm{R} \text { hemisphere blood flow }\end{array}$ & \\
\hline $\begin{array}{l}\text { Mathew \& } \\
\text { Wilson (1993) }\end{array}$ & ${ }^{133} \mathrm{Xe}-\mathrm{SPECT}$ & $35 / 0$ & $21.7(8)$ & $\mathrm{R}$ & $1.75 \% / 3.55 \%$ & s & Baseline & $\begin{array}{l}\text { Scintillation } \\
\text { detector }\end{array}$ & Resting state & $\begin{array}{l}\text { Global CBF } \\
\mathrm{R} \text { frontal blood flow }\end{array}$ & \\
\hline \multicolumn{12}{|c|}{ Functional (resting state) after THC administration } \\
\hline $\begin{array}{l}\text { Volkow et al. } \\
\text { (1996) }\end{array}$ & ${ }^{18} \mathrm{~F}-\mathrm{FDG}-\mathrm{PET}$ & $8 / 8$ & $31(6) / 35(7)$ & $\mathrm{C}$ & $2 \mathrm{mg}$ & i.v. & Baseline & ROI & Resting state & $\begin{array}{l}\text { PFC blood flow } \\
\text { OFC blood flow } \\
\text { Basal ganglia blood flow }\end{array}$ & Cerebellar blood flow \\
\hline $\begin{array}{l}\text { Mathew et al. } \\
\text { (1997) }\end{array}$ & $\mathrm{H}_{2}{ }^{15} \mathrm{O}-\mathrm{PET}$ & $32 / 0$ & $32.5(7.6)$ & $\mathrm{R}$ & $\begin{array}{l}0.15 / 0.25 \mathrm{mg} / \\
\min \end{array}$ & i.v. & Placebo & ROI & Resting state & $\begin{array}{l}\text { Global CBF } \\
\mathrm{R} \text { hemisphere blood flow } \\
\mathrm{L} / \mathrm{R} \text { frontal, insula } \\
\text { and ACC blood flow }\end{array}$ & \\
\hline $\begin{array}{l}\text { Mathew et al. } \\
\text { (1998) }\end{array}$ & $\mathrm{H}_{2}{ }^{15} \mathrm{O}-\mathrm{PET}$ & $46 / 0$ & $29.0(6.1)$ & $\mathrm{R}$ & $\begin{array}{l}0.15 / 0.25 \mathrm{mg} / \\
\min \end{array}$ & i.v. & Baseline & ROI & Resting state & $\begin{array}{l}\text { L/R ACC blood flow } \\
\mathrm{L} / \mathrm{R} \text { insula blood flow } \\
\mathrm{L} / \mathrm{R} \text { cerebellum } \\
\text { blood flow } \\
\mathrm{L} / \mathrm{R} \text { frontal blood flow }\end{array}$ & Cerebellar blood flow \\
\hline $\begin{array}{l}\text { Mathew et al. } \\
(1999)\end{array}$ & $\mathrm{H}_{2}{ }^{15} \mathrm{O}-\mathrm{PET}$ & $59 / 0$ & $31.7(7.5)$ & $\mathrm{R}$ & $\begin{array}{l}0.15 / 0.25 \mathrm{mg} / \\
\min \end{array}$ & i.v. & Baseline & $\mathrm{ROI}^{\mathrm{b}}$ & Resting state & $\begin{array}{l}\mathrm{L} / \mathrm{R} \text { ACC blood flow } \\
\mathrm{R} \text { frontal blood flow } \\
\mathrm{R} \text { insula blood flow }\end{array}$ & $\begin{array}{l}\text { Basal ganglia, thalamus, } \\
\text { hippocampus and } \\
\text { amygdala blood flow }\end{array}$ \\
\hline $\begin{array}{l}\text { Mathew et al. } \\
(2002)\end{array}$ & $\mathrm{H}_{2}{ }^{15} \mathrm{O}-\mathrm{PET}$ & $47 / 0$ & $32.0(8.3)$ & C & $\begin{array}{l}0.15 / 0.25 \mathrm{mg} / \\
\min \end{array}$ & i.v. & Baseline & $\mathrm{ROI}^{\mathrm{b}}$ & Resting state & $\begin{array}{l}\text { R ACC blood flow } \\
\text { R insula blood flow } \\
\text { Ratio of anterior: } \\
\text { posterior blood flow } \\
\text { L/R cerebellum } \\
\text { blood flow }\end{array}$ & \\
\hline $\begin{array}{l}\text { Bossong et al. } \\
(2009)\end{array}$ & $\begin{array}{l}{\left[{ }^{11} \mathrm{C}\right] \text { Raclopride- }} \\
\text { PET }\end{array}$ & $7 / 0$ & $21.9(2.7)$ & $\mathrm{R}$ & $8 \mathrm{mg}$ & $\mathrm{i}$ & Placebo & $\mathrm{ROI}^{\mathrm{b}}$ & Resting state & & $\begin{array}{l}\mathrm{BP}_{\mathrm{ND}} \text { in: } \\
\text { Ventral striatum } \\
\text { Precommissural } \\
\text { dorsal putamen }\end{array}$ \\
\hline
\end{tabular}




\begin{tabular}{|c|c|c|c|c|c|c|c|c|c|c|c|}
\hline Author & Method & $\begin{array}{l}\text { Users/ } \\
\text { controls }\end{array}$ & $\begin{array}{l}\text { Mean age } \\
\text { (s.D.) users/ } \\
\text { controls }\end{array}$ & $\begin{array}{l}\text { Users' } \\
\text { type }\end{array}$ & THC dose $\mathrm{e}^{\mathrm{a}}$ & $\begin{array}{l}\text { THC } \\
\text { route }\end{array}$ & $\begin{array}{l}\text { Comparison } \\
\text { placebo/ } \\
\text { baseline }\end{array}$ & $\begin{array}{l}\text { Image } \\
\text { analysis }\end{array}$ & Condition & $\begin{array}{l}\text { Greater volume/ } \\
\text { resting blood flow/ } \\
\mathrm{BP}_{\mathrm{ND}} / \text { activation } \\
\text { in users }\end{array}$ & $\begin{array}{l}\text { Reduced volume/ } \\
\text { resting blood flow / } \\
\mathrm{BP}_{\mathrm{ND}} / \text { activation } \\
\text { in users }\end{array}$ \\
\hline \multicolumn{12}{|c|}{ Functional (resting state) after CBD administration } \\
\hline $\begin{array}{l}\text { Crippa et al. } \\
(2004)\end{array}$ & ${ }^{99 \mathrm{~m}} \mathrm{Tc}-\mathrm{SPECT}$ & $0 / 10$ cross-over & $29.8(5.1)$ & $\mathrm{N}$ & CBD: $400 \mathrm{mg}$ & o & Placebo & $\begin{array}{l}\text { Voxel- } \\
\text { based }\end{array}$ & Resting state & $\begin{array}{l}\text { L parahippocampal } \\
\text { gyrus blood flow }\end{array}$ & $\begin{array}{l}\text { L amygdala- } \\
\text { hippocampal, } \\
\text { hypothalamus } \\
\text { L posterior cingulate } \\
\text { gyrus blood flow }\end{array}$ \\
\hline \multicolumn{12}{|c|}{ Functional (cognitive task) after marijuana cigarette } \\
\hline $\begin{array}{l}\text { O'Leary et al. } \\
(2002)\end{array}$ & $\mathrm{H}_{2}{ }^{15} \mathrm{O}-\mathrm{PET}$ & $12 / 0$ & $30.5(8)$ & $\mathrm{R}$ & $20 \mathrm{mg}$ & $\mathrm{s}$ & Placebo & Voxel-based $^{\mathrm{b}}$ & $\begin{array}{l}\text { Dichotic } \\
\text { listening task }\end{array}$ & $\begin{array}{l}\mathrm{L} / \mathrm{R} \text { temporal } \\
\text { activation } \\
\mathrm{L} \text { ventral frontal } \\
\text { activation } \\
\mathrm{R} \text { insula and } \\
\text { putamen activation } \\
\mathrm{L} / \mathrm{R} \text { cerebellum } \\
\text { activation }\end{array}$ & $\begin{array}{l}\mathrm{L} / \mathrm{R} \text { frontal } \\
\text { activation } \\
\text { L STG activation } \\
\text { R occipital } \\
\text { activation }\end{array}$ \\
\hline $\begin{array}{l}\text { O'Leary et al. } \\
(2003)\end{array}$ & $\mathrm{H}_{2}{ }^{15} \mathrm{O}-\mathrm{PET}$ & $\begin{array}{l}12 \text { heavy } \\
12 \\
\text { moderate/0 }\end{array}$ & $21.7(1.4)$ & $\mathrm{R}$ & $20 \mathrm{mg}$ & $\mathrm{s}$ & Baseline & Voxel-based $^{\mathrm{b}}$ & $\begin{array}{l}\text { Self-paced } \\
\text { counting task }\end{array}$ & $\begin{array}{l}\text { Both groups: } \\
\text { ACC, R cerebellar } \\
\text { and L OFC activation } \\
\text { Moderate users: } \\
\text { L/R ventral frontal } \\
\text { lobe, R DLPFC, } \\
\text { R mesial frontal, } \\
\text { R middle temporal and } \\
\text { R parietal activation } \\
\text { Heavy users: } \\
\text { L cerebellar, } \\
\text { L thalamus, L } \\
\text { hippocampal, R frontal } \\
\text { and L STG activation }\end{array}$ & $\begin{array}{l}\text { Both groups: } \\
\text { R occipital, temporal and } \\
\text { frontal activation }\end{array}$ \\
\hline $\begin{array}{l}\text { O'Leary et al. } \\
(2007)\end{array}$ & $\mathrm{H}_{2}{ }^{15} \mathrm{O}-\mathrm{PET}$ & $12 / 0$ & $23.5(4.3)$ & $\mathrm{R}$ & $20 \mathrm{mg}$ & $\mathrm{s}$ & Placebo & $\begin{array}{l}\text { Voxel- } \\
\text { based }\end{array}$ & $\begin{array}{l}\text { Dichotic } \\
\text { listening task }\end{array}$ & $\begin{array}{l}\text { OFC, ACC, temporal pole, } \\
\text { insula and cerebellum } \\
\text { activation }\end{array}$ & $\begin{array}{l}\text { Visual and auditory } \\
\text { cortices activation }\end{array}$ \\
\hline $\begin{array}{l}\text { Phan et al. } \\
\text { (2008) }\end{array}$ & fMRI & $0 / 16$ & $20.8(2.6)$ & $\mathrm{R}$ & $7.5 \mathrm{mg}$ & o & Placebo & Voxel-based $^{\mathrm{b}}$ & $\begin{array}{l}\text { Emotional face } \\
\text { processing } \\
\text { task }\end{array}$ & & $\mathrm{R}$ amygdala \\
\hline
\end{tabular}




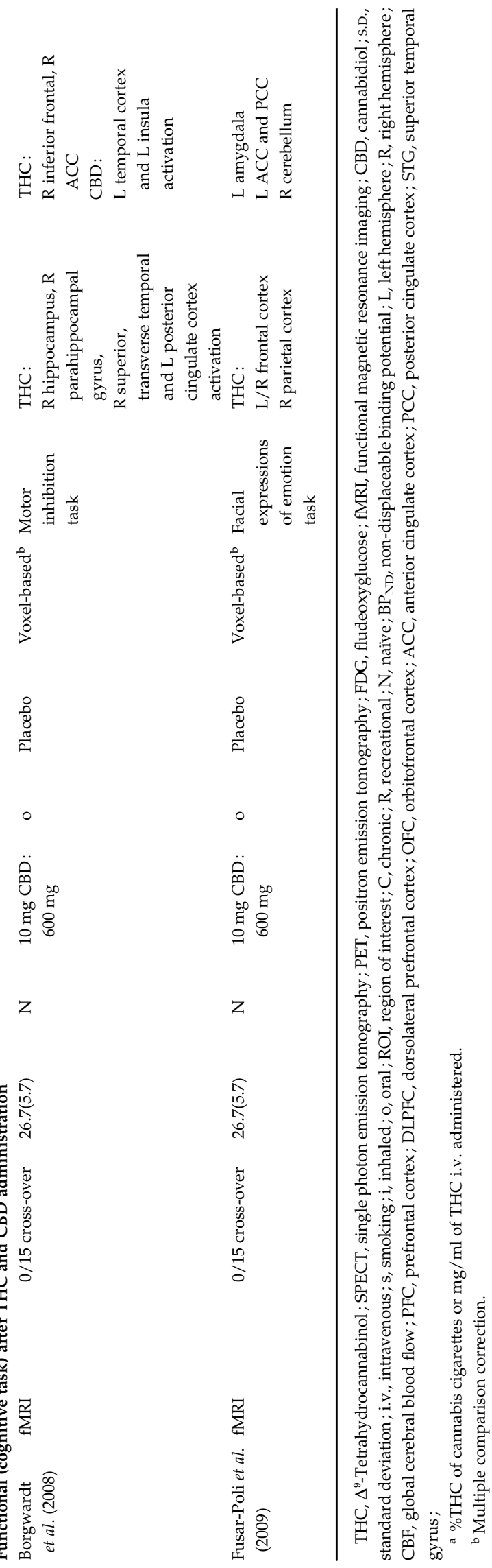

cannabis users (Volkow et al. 1996; Mathew et al. 1997, 1999). Following administration of THC, the subjective level of intoxication was correlated positively with increases in the anterior/posterior ratio of brain activity (Mathew et al. 2002); and also activity in the ACC (Mathew et al. 1997), frontal (Mathew et al. 1997, 1999) and cerebellar cortices (Volkow et al. 1996). TDI scores have also been negatively correlated with cerebellar activity (Mathew et al. 1998). Moreover, the severity of paranoid symptoms following intravenous THC administration was correlated with the plasma level of THC (Volkow et al. 1996).

Finally, Bossong et al. 2009 studied the effects of THC inhalation on $\left[{ }^{11} \mathrm{C}\right]$ raclopride specific binding (a dopamine $D_{2} / D_{3}$ receptor tracer) in seven healthy subjects, finding a reduction in the ventral striatum and dorsal putamen, which is consistent with an increase in dopamine levels in these regions.

After CBD administration. One study explored the acute effect of CBD relative to placebo in a sample of healthy subjects (Crippa et al. 2004). It showed reduced activity in medial temporal areas including the left amygdalahippocampal complex, extending to the hypothalamus, and the left posterior cingulate gyrus and an increased activity in the left parahippocampal gyrus. No correlations were observed between subjective anxiety ratings (the Visual Analogue Mood Scale, VAMS) and the activity in the brain areas where the effects of CBD had been predicted a priori, or in the other unpredicted areas after correction for multiple comparisons.

\section{Acute effects of cannabis on activation during cognitive tasks}

After smoking marijuana cigarettes. Three PET studies have examined the acute effect of marijuana cigarettes with $20 \mathrm{mg}$ of THC on rCBF while subjects were performing a cognitive task (Table 1).

(a) Attention. Two imaging studies used an attentional paradigm. O'Leary et al. (2002) evaluated the effects of marijuana cigarettes with THC on $\mathrm{rCBF}$ in regular cannabis users while performing a dichotic listening task after 4 days of abstinence. Marijuana with THC use was associated with increased $\mathrm{rCBF}$ (relative to a cigarette containing marijuana with the THC removed) in the left ventral frontal cortex, right insula, bilateral temporal pole, ACC, temporal and cerebellar cortices, whereas there was decreased activity in the left superior temporal gyrus (O'Leary et al. 2002). In a subsequent study by the same group, 12 recreational cannabis users were tested ( $\mathrm{O}^{\prime}$ Leary et al. 2007). rCBF was measured during a tasks requiring attention to left and right ears in different conditions, after smoking 
marijuana cigarettes with or without THC, at least a week apart using a double-blind design. After smoking marijuana cigarettes with $\mathrm{THC}$, there was an increase in $\mathrm{rCBF}$ increase in the orbitofrontal cortex, ACC, temporal pole, insula and cerebellum. On the contrary, smoking marijuana cigarettes with $20 \mathrm{mg}$ of THC lowered rCBF in auditory cortices compared to marijuana cigarette without THC. However, THC did not alter the normal pattern of attention-related $\mathrm{rCBF}$ asymmetry (greater $\mathrm{rCBF}$ in the temporal lobe contralateral to the direction of attention) observed after subjects smoked marijuana cigarettes without THC. As attentional neuroanatomical networks are known to include prefrontal and posterior parietal regions (Berger \& Posner, 2000), these results suggest alterations of the functional anatomical substrate of attentional processes as a consequence of acute cannabis use.

(b) Motor performance. The above group ( $\mathrm{O}^{\prime}$ Leary et al. 2003) has studied the acute effects of smoking marijuana cigarettes with $20 \mathrm{mg}$ of THC in heavy and moderate cannabis users while they performed a selfpaced counting task. In both groups, marijuana with THC was associated with increased activation in the cerebellum, the left orbitofrontal cortex and the ACC; and decreased activation in the right temporal, occipital and dorsolateral prefrontal cortices. The magnitude of this effect on right ventral and dorsolateral frontal activation was greater in the moderate than in the heavy users. Smoking marijuana cigarettes was also associated with faster response times, which was related to the change in cerebellar clock activity (O'Leary et al. 2003).

After THC administration. Three fMRI studies have examined the acute effect of THC on rCBF while subjects were performing a cognitive task (Table 1). Two of them (Borgwardt et al. 2008; Fusar-Poli et al. 2009) compared the two main compounds of cannabis, THC and $\mathrm{CBD}$, controlled by placebo.

(a) Motor response inhibition. Fifteen healthy volunteers performed a motor inhibition task (Go/No-Go) following oral administration of either $10 \mathrm{mg}$ of THC or $600 \mathrm{mg}$ of CBD or a placebo (Borgwardt et al. 2008). Relative to the placebo, THC attenuated activation in the right inferior frontal cortex and the anterior cingulate gyrus. Conversely, THC was associated with greater activation in the right hippocampus/parahippocampal gyrus, right superior and transverse temporal gyri and the left posterior cingulated cortex. These THC-induced changes were not associated with behavioural effects. By contrast, CBD deactivated the left temporal cortex and insula. These results suggested that THC modulates brain function during response inhibition, whereas the effects of $\mathrm{CBD}$ are evident in other regions that do not mediate this cognitive process.

(b) Emotional processing. Two studies evaluated facial emotional processing after the administration of cannabinoids. Fusar-Poli et al. (2009) evaluated 15 healthy volunteers on three separate occasions while viewing faces that implicitly induced different emotional processing. Each scanning session was preceded by a single oral dose of $10 \mathrm{mg}$ of THC, $600 \mathrm{mg}$ of CBD or placebo. After CBD administration, reduced activation in the amygdala and the anterior and posterior cingulated cortices was observed while subjects processed intensely fearful faces. Conversely, THC administration modulated activation mainly in the frontal and parietal regions. Overall, the results suggested that both THC and CBD have effects on neural response to fearful faces. The second study (Phan et al. 2008) evaluated the effects of $7.5 \mathrm{mg}$ of THC on amygdala reactivity to social signals of threat (fearful and angry faces) in 16 recreational cannabis users. The results suggest that THC significantly attenuated amygdala activation to threatening faces but had no effect on visual and motor cortex activation.

\section{Non-acute effects (see Table 2)}

\section{Structural studies}

Eight structural MRI studies have investigated grey matter volume in chronic cannabis users (Table 2). Although all of these studies were methodologically rigorous, three of them did not find any significant abnormalities in cannabis users relative to the controls (Block et al. 2000a; Tzilos et al. 2005; Jager et al. 2007). Two studies reported structural brain differences associated with chronic cannabis use (Matochik et al. 2005; Yücel et al. 2008). Matochik et al. (2005) found that cannabis users had a smaller grey matter volume than the controls in the right parahippocampal gyrus, and a larger white matter volume in the contralateral parahippocampal and fusiform regions. Differences in grey matter volume in the right lentiform nucleus, brain stem, precentral gyrus and right thalamus were also found. More recently, Yücel et al. (2008) report bilateral volumetric reductions in the hippocampal and amygdalar areas in a group of 15 chronic cannabis users compared with non-users. The volume of the left hippocampus was inversely associated with the severity of positive psychotic symptoms, as assessed by the Scale for the Assessment of Positive Symptoms (SAPS). Finally, three studies have used DTI to examine the integrity of white matter tracts in cannabis 
users. Two of them found no differences between cannabis users and controls (Gruber \& YurgelunTodd, 2005; DeLisi et al. 2006). The third study reported a significant reduction in mean diffusivity, but no decrease in fractional anisotropy associated with cannabis use, in the prefrontal section of the corpus callosum (Arnone et al. 2008). Taken together, these structural neuroimaging studies provide minimal evidence of major cannabis effects on brain structure, both in regional grey matter volumes and in the integrity of white matter fibres. Subtle alterations may be easier to detected using functional methods.

\section{Non-acute effects on resting state activity}

We included seven case-control studies that compared resting rCBF in cannabis users and healthy subjects. The imaging methods used were ${ }^{133}$ Xe-SPECT (Mathew et al. 1986; Tunving et al. 1986; Lundqvist et al. 2001), $\mathrm{H}_{2}{ }^{15} \mathrm{O}-\mathrm{PET}$ (Block et al. 2000b), [18F]-FDGPET (Sevy et al. 2008), [ ${ }^{11}$ C]raclopride-PET (Sevy et al. 2008) and dynamic susceptibility contrast (DSC)-MRI (DSMRI; Sneider et al. 2008). In a group of nine chronic cannabis users, assessed within 1 week of drug cessation, Tunving et al. (1986) found a reduction in global CBF relative to controls that did not correlate with the duration of cannabis consumption. When four of the cannabis users were rescanned following a further abstinence period, an increase in CBF relative to baseline was observed. Lundqvist et al. (2001) also report lower global CBF in cannabis users than controls after 5 days of abstinence, and described reduced $\mathrm{rCBF}$ in the right prefrontal and superior frontal cortex. Block et al. (2000b) report reduced bilateral cerebellar and ventral prefrontal activity but also greater right anterior cingulate $\mathrm{rCBF}$ in 17 young chronic marihuana users after $26 \mathrm{~h}$ of abstinence. Mathew et al. (1986) assessed 17 chronic cannabis users after $12 \mathrm{~h}$ of abstinence and found no differences in either global or rCBF between cannabis users and controls. Sneider et al. (2008) examined changes in regional blood volume (rCBV) in a group of 17 healthy controls and 15 cannabis users. Imaging data were collected between 6 and $36 \mathrm{~h}$ after the subjects' last cannabis use, and again after 7 and 28 days of supervised cannabis abstinence. Their findings demonstrated that, after 7 days of abstinence, cannabis users continued to display the same pattern of activation, characterized by increased $\mathrm{rCBV}$ in the right frontal, bilateral temporal lobes and the cerebellum. Nevertheless, after 28 days of abstinence only the temporal and cerebellar areas showed increased activity, suggesting that frontal regions begin to normalize with prolonged cannabis abstinence whereas other regions continue to show altered neural activity.
Finally, a pattern of reduced metabolism in the right orbitofrontal region and striatum bilaterally was described in six subjects with cannabis dependence compared with six healthy controls. However, there were no differences between groups in striatal $D_{2} / D_{3}$ receptor availability. No correlations between striatal $\left[{ }^{11} \mathrm{C}\right]$ raclopride binding potential and glucose metabolism were observed (Sevy et al. 2008).

\section{Non-acute effects on activation during cognitive tasks}

We included 10 studies that compared regional activation during performance of a cognitive task in cannabis users and healthy controls (Table 1).

Memory and attention. Cannabis is known to have robust effects on short-term episodic memory, which might be mediated by several mechanisms, including the inhibition of gamma-aminobutyric acid (GABA), glutamate and dopamine release (Ranganathan \& D'Souza, 2006). Using ${ }^{15} \mathrm{OH}_{2} \mathrm{O}-\mathrm{PET}$, Block et al. (2002) report that 18 chronic cannabis users (after $26 \mathrm{~h}$ of abstinence) had worst performance with an associative memory task. This was associated with reduced activation in the right prefrontal cortex but greater activation in posterior cerebellum relative to 13 healthy controls. Similar activity in the right dorsolateral prefrontal cortex and attenuated bilateral parahippocampal activation were reported by Jager et al. (2007) in 20 chronic cannabis users after 7 days of abstinence compared with 20 healthy controls. There were no differences in task performance between groups.

Chang et al. (2006) used fMRI to examine visual attention in 24 chronic cannabis users, abstinent for $24 \mathrm{~h}$, relative to 19 healthy controls. Cannabis users showed decreased activation in the right prefrontal, medial and dorsal parietal cortices and medial cerebellar regions. They also showed greater activation in left frontal subgyral, right parietal subgyral and left occipital regions. Early age of first cannabis use and greater estimated cumulative use of THC were both associated with reduced activation in the right prefrontal cortex and medial cerebellum, brain regions that have high concentrations of $\mathrm{CB}_{1}$ receptors.

Working memory. Using fMRI, Kanayama et al. (2004) measured activation during a spatial working memory task in 12 heavy cannabis users, after $36 \mathrm{~h}$ of abstinence, and 10 healthy controls. There were no group differences in task performance but the cannabis users displayed greater activation than controls in the right superior, middle and inferior frontal gyri, the bilateral ACC, right precentral and superior temporal gyri, and in the basal ganglia. Jager et al. (2006) measured activation during a modified Sternberg item recognition 
Table 2. Non-acute effects of cannabis use: structural studies (volumetric or DTI) and functional studies (resting state or with a cognitive task)

\begin{tabular}{|c|c|c|c|c|c|c|c|c|}
\hline Author & Method & $\begin{array}{l}\text { Users/ } \\
\text { Controls }\end{array}$ & $\begin{array}{l}\text { Mean age } \\
\text { (s.D.) } \\
\text { users/controls }\end{array}$ & $\begin{array}{l}\text { Users' } \\
\text { type }\end{array}$ & $\begin{array}{l}\text { Image } \\
\text { analysis }\end{array}$ & Condition & $\begin{array}{l}\text { Greater volume/resting blood } \\
\text { flow/MD/activation in users }\end{array}$ & $\begin{array}{l}\text { Reduced volume/resting } \\
\text { blood flow/activation in users }\end{array}$ \\
\hline \multicolumn{9}{|c|}{ Structural (volumetric or DTI) } \\
\hline $\begin{array}{l}\text { Block et al. } \\
(2000 a)\end{array}$ & MRI & $18 / 13$ & $\begin{array}{r}22.3(0.5) / \\
22.6(0.5)\end{array}$ & $\mathrm{C}$ & $\begin{array}{l}\text { Voxel-based } \\
\text { ROI }\end{array}$ & - & & \\
\hline $\begin{array}{l}\text { Tzilos et al. } \\
\text { (2005) }\end{array}$ & MRI & $22 / 26$ & $\begin{array}{r}38.1(6.2) / \\
29.5(8.5)\end{array}$ & $\mathrm{C}$ & $\begin{array}{l}\text { Voxel-based } \\
\text { ROI }\end{array}$ & - & & \\
\hline $\begin{array}{l}\text { Matochik } \\
\text { et al. (2005) }\end{array}$ & MRI & $11 / 8$ & $\begin{array}{l}25.4(5) / \\
29.7(4.7)\end{array}$ & $\mathrm{C}$ & $\begin{array}{l}\text { Voxel-based } \\
\text { ROI }^{\text {a }}\end{array}$ & - & $\begin{array}{l}\text { Precentral and } \mathrm{R} \text { thalamic grey matter } \\
\mathrm{L} \text { parahippocampal and fusiform, } \mathrm{R} \\
\text { lentiform and brain stem white } \\
\text { matter }\end{array}$ & $\begin{array}{l}\mathrm{R} \text { parahippocampal grey matter } \\
\mathrm{L} \text { parietal white matter }\end{array}$ \\
\hline $\begin{array}{l}\text { Jager et al. } \\
\text { (2007) }\end{array}$ & MRI & $20 / 20$ & $\begin{array}{r}24.5(5.2) / \\
23.6(3.9)\end{array}$ & $\mathrm{C}$ & $\begin{array}{l}\text { Voxel-based } \\
\text { ROI }^{\mathrm{a}}\end{array}$ & - & & \\
\hline $\begin{array}{l}\text { Gruber et al. } \\
(2005)\end{array}$ & DTI & $9 / 9$ & $\begin{array}{l}26(3.6) / \\
26.2(3.1)\end{array}$ & & $\begin{array}{l}\text { Voxel-based }^{\text {a }} \\
\text { ROI }\end{array}$ & & & \\
\hline $\begin{array}{l}\text { DeLisi et al. } \\
\text { (2006) }\end{array}$ & DTI & $10 / 10$ & $\begin{array}{l}21.1(2.9) / \\
23(4.4)\end{array}$ & $\mathrm{C}$ & $\begin{array}{l}\text { Voxel-based } \\
\text { ROI }\end{array}$ & - & & \\
\hline $\begin{array}{l}\text { Yücel et al. } \\
\text { (2008) }\end{array}$ & MRI & $15 / 16$ & $\begin{array}{r}38.8(8.9) / \\
36.4(9.8)\end{array}$ & $\mathrm{C}$ & $\begin{array}{l}\text { Voxel-based } \\
\text { ROI }\end{array}$ & - & & $\begin{array}{l}\mathrm{L} / \mathrm{R} \text { hippocampus } \\
\mathrm{L} / \mathrm{R} \text { amygdala }\end{array}$ \\
\hline $\begin{array}{l}\text { Arnone et al. } \\
\text { (2008) }\end{array}$ & DTI & $11 / 11$ & $\begin{array}{l}25.0(2.9) / \\
23.3(2.9)\end{array}$ & $\mathrm{C}$ & Voxel-based & - & Prefrontal regions of corpus callosum & \\
\hline \multicolumn{9}{|c|}{ Functional (resting state) } \\
\hline $\begin{array}{l}\text { Tunving et al. } \\
\text { (1986) }\end{array}$ & ${ }^{133} \mathrm{Xe}$-SPECT & $9 / 9$ & $\begin{array}{l}25(4.89) / \\
\text { ND }\end{array}$ & $\mathrm{C}$ & $\begin{array}{l}\text { Scintillation } \\
\text { detector }\end{array}$ & Resting state & & Global CBF \\
\hline $\begin{array}{l}\text { Mathew et al. } \\
\text { (1986) }\end{array}$ & ${ }^{133} \mathrm{Xe-SPECT}$ & $17 / 17$ & $\begin{array}{l}25.5(8) / \\
\text { ND }\end{array}$ & $\mathrm{C}$ & $\begin{array}{l}\text { Scintillation } \\
\text { detector }\end{array}$ & Resting state & & \\
\hline $\begin{array}{l}\text { Block et al. } \\
(2000 b)\end{array}$ & $\mathrm{H}_{2}{ }^{15} \mathrm{O}-\mathrm{PET}$ & $17 / 12$ & $\begin{array}{r}22.4(0.5) / \\
22.6(0.5)\end{array}$ & $\mathrm{C}$ & Voxel-based & Resting state & $\mathrm{R}$ anterior cingulate blood flow & $\begin{array}{l}\mathrm{L} / \mathrm{R} \text { cerebellar and ventral } \\
\text { prefrontal blood flow }\end{array}$ \\
\hline $\begin{array}{l}\text { Lundqvist } \\
\text { et al. (2001) }\end{array}$ & ${ }^{133} \mathrm{Xe}$-SPECT & $12 / 14$ & $\begin{array}{l}29.8(5) / \\
27.8(5.2)\end{array}$ & $\mathrm{C}$ & Voxel-based & Resting state & & $\begin{array}{l}\text { Global CBF } \\
\text { R PFC blood flow } \\
\text { R superior frontal blood flow }\end{array}$ \\
\hline $\begin{array}{l}\text { Sneider et al. } \\
(2008)\end{array}$ & DSC-MRI & $15 / 17$ & $\begin{array}{r}38.3(5.6) / \\
26.4(3.8)\end{array}$ & $\mathrm{C}$ & ROI & Resting state & $\begin{array}{l}7 \text { days: } \mathrm{R} \text { frontal } \mathrm{L} / \mathrm{R} \text { temporal } \\
\text { cerebellum } \\
28 \text { days: } \mathrm{L} \text { temporal cerebellum }\end{array}$ & \\
\hline $\begin{array}{l}\text { Sevy et al. } \\
(2008)\end{array}$ & ${ }^{18} \mathrm{~F}-\mathrm{FDG}-\mathrm{PET}$ & $6 / 6$ & $\begin{array}{c}20.0(1.0) / \\
20.0(1.0)\end{array}$ & $\mathrm{C}$ & Voxel-based & Resting state & & $\begin{array}{l}\mathrm{R} \text { OFC } \\
\mathrm{R} \text { posterior parietal cortex } \\
\mathrm{L} / \mathrm{R} \text { putamen }\end{array}$ \\
\hline
\end{tabular}




\begin{tabular}{|c|c|c|c|c|c|c|c|c|}
\hline $\begin{array}{l}\text { Sevy et al. } \\
(2008)\end{array}$ & $\begin{array}{l}{\left[{ }^{11} \mathrm{C}\right]-} \\
\text { raclopride- } \\
\text { PET }\end{array}$ & $6 / 6$ & $\begin{array}{c}20.0(1.0) / \\
20.0(1.0)\end{array}$ & $\mathrm{C}$ & $\begin{array}{l}\text { Voxel-based } \\
\text { Volume of } \\
\text { interest }\end{array}$ & Resting state & & \\
\hline \multicolumn{9}{|c|}{ Functional (cognitive task) } \\
\hline $\begin{array}{l}\text { Block et al. } \\
(2002)\end{array}$ & $\mathrm{H}_{2}{ }^{15} \mathrm{O}-\mathrm{PET}$ & $18 / 13$ & $\begin{array}{r}22.3(0.5) / \\
22.6(0.5)\end{array}$ & $\mathrm{C}$ & Voxel-based & Verbal memory & & $\mathrm{L} / \mathrm{R}$ PFC activation \\
\hline $\begin{array}{l}\text { Pillay et al. } \\
\text { (2004) }\end{array}$ & fMRI & $9 / 16$ & $\begin{array}{l}37(6) / \\
29(10.3)\end{array}$ & $\mathrm{R}$ & $\begin{array}{l}\text { ROI } \\
\text { Voxel-based }\end{array}$ & $\begin{array}{l}\text { Finger } \\
\text { sequencing }\end{array}$ & & $\begin{array}{l}\mathrm{L} / \mathrm{R} \text { SMA activation } \\
\mathrm{L} / \mathrm{R} \text { ACC activation }\end{array}$ \\
\hline $\begin{array}{l}\text { Kanayama } \\
\text { et al. }(2004)\end{array}$ & fMRI & $12 / 10$ & $\begin{array}{l}37(7.4) / \\
27.8(7.9)\end{array}$ & $\mathrm{C}$ & Voxel-based & $\begin{array}{l}\text { Spatial working } \\
\text { memory }\end{array}$ & $\begin{array}{l}\mathrm{R} \text { inferior and superior frontal gyrus } \\
\text { activation, } \mathrm{L} / \mathrm{R} \text { middle frontal gyrus } \\
\text { activation, } \mathrm{R} \text { STG activation } \\
\mathrm{R} \text { precentral gyrus activation } \\
\text { Bilateral ACC activation, } \mathrm{L} / \mathrm{R} \text { caudate } \\
\text { activation }\end{array}$ & $\mathrm{L} / \mathrm{R}$ middle frontal activation \\
\hline $\begin{array}{l}\text { Eldreth et al. } \\
\text { (2004) }\end{array}$ & $\mathrm{H}_{2}{ }^{15} \mathrm{O}-\mathrm{PET}$ & $11 / 11$ & $25 / 29$ & $\mathrm{C}$ & Voxel-based $^{\mathrm{a}}$ & Stroop & $\begin{array}{l}\mathrm{L} / \mathrm{R} \text { hippocampal activation } \\
\mathrm{R} \text { paracentral activation } \\
\mathrm{L} \text { occipital activation }\end{array}$ & $\begin{array}{l}\text { L DLPFC and ACC activation } \\
\text { R VMPFC and DLPFC } \\
\text { activation }\end{array}$ \\
\hline $\begin{array}{l}\text { Bolla et al. } \\
\text { (2005) }\end{array}$ & $\mathrm{H}_{2}{ }^{15} \mathrm{O}-\mathrm{PET}$ & $11 / 11$ & $\begin{array}{l}26(21-35) / \\
31\end{array}$ & $\mathrm{C}$ & Voxel-based $^{\mathrm{a}}$ & Iowa Gambling & $\begin{array}{l}\text { L cerebellar activation } \\
\text { L parietal activation }\end{array}$ & $\begin{array}{l}R \text { OFC activation } \\
R \text { DLPFC activation }\end{array}$ \\
\hline $\begin{array}{l}\text { Gruber et al. } \\
\text { (2005) }\end{array}$ & fMRI & $9 / 9$ & $\begin{array}{l}26(3.6) / \\
26.2(3.1)\end{array}$ & $\mathrm{C}$ & $\begin{array}{l}\text { Voxel-based }^{\mathrm{a}} \\
\text { ROI }\end{array}$ & Stroop & $\mathrm{R}$ DLPFC and L/R ACC activation & \\
\hline $\begin{array}{l}\text { Chang et al. } \\
\text { (2006) }\end{array}$ & fMRI & $24 / 19$ & $\begin{array}{l}27.9(10.8) / \\
30.6(8.0)\end{array}$ & $\mathrm{C}$ & $\begin{array}{l}\text { Voxel-based }^{a} \\
\text { ROI }\end{array}$ & $\begin{array}{l}\text { Visual attention } \\
\text { task }\end{array}$ & $\begin{array}{l}\text { Parietal cortex activation } \\
\text { Occipital cortex activation }\end{array}$ & $\begin{array}{l}\mathrm{R} \text { PFC activation } \\
\mathrm{R} \text { parietal cortex activation } \\
\text { Cerebellar activation }\end{array}$ \\
\hline $\begin{array}{l}\text { Jager et al. } \\
(2006)\end{array}$ & fMRI & $10 / 10$ & $\begin{array}{r}22.7(4.2) / \\
22.8(2.9)\end{array}$ & $\mathrm{C}$ & $\begin{array}{l}\text { Voxel-based }^{\mathrm{a}} \\
\text { ROI }\end{array}$ & $\begin{array}{l}\text { Working } \\
\text { memory }\end{array}$ & $\begin{array}{l}\text { L superior parietal cortex activation } \\
\text { (after practise) }\end{array}$ & \\
\hline $\begin{array}{l}\text { Murphy et al. } \\
\text { (2006) }\end{array}$ & fMRI & $20 / 25$ & $\begin{array}{r}23(19-45) / \\
25(19-36)\end{array}$ & $\mathrm{C}$ & $\begin{array}{l}\text { Voxel-based }^{\text {a }} \\
\text { ROI }\end{array}$ & $\begin{array}{l}\text { Finger-tapping } \\
\text { task }\end{array}$ & & \\
\hline $\begin{array}{l}\text { Jager et al. } \\
(2007)\end{array}$ & fMRI & $20 / 20$ & $\begin{array}{r}24.5(5.2) / \\
23.6(3.9)\end{array}$ & $\mathrm{C}$ & $\begin{array}{l}\text { Voxel-based } \\
\text { ROI }^{\mathrm{a}}\end{array}$ & $\begin{array}{l}\text { Associative } \\
\text { memory }\end{array}$ & & $\begin{array}{l}\text { L/R Parahippocampal regions } \\
\text { R DLPFC }\end{array}$ \\
\hline
\end{tabular}

DTI, Diffusion tensor imaging; S.D., standard deviation; MRI, magnetic resonance imaging; SPECT, single photon emission tomography; PET, positron emission tomography; DSC, dynamic susceptibility contrast; FDG, fludeoxyglucose; fMRI, functional magnetic resonance imaging; L, Left hemisphere; R, right hemisphere; C, chronic; R, recreational ; ROI, region of interest; CBF, global cerebral blood flow ; MD, mean diffusivity ; PFC, prefrontal cortex; DLPFC, dorsolateral prefrontal cortex; VMPFC, ventromedial prefrontal cortex; OFC, orbitofrontal cortex; ACC, anterior cingulate cortex; STG, superior temporal gyrus; SMA, supplementary motor area.

${ }^{\text {a }}$ Multiple comparison correction. 
task in 10 chronic cannabis users, after 1 week of cessation of use, and 10 controls. Again there were no task performance differences between groups but the controls shown decreased activation in the left superior parietal cortex over repeated trials, which did not occur with the cannabis users, suggesting a compensatory effect in cannabis users.

Inhibition. Eldreth et al. (2004), using ${ }^{15} \mathrm{OH}_{2} \mathrm{O}-\mathrm{PET}$, and Gruber \& Yurgelun-Todd (2005), using fMRI, examined the degree of inhibitory control during a Stroop task in chronic cannabis users 25 and 14 days after cessation of use, respectively. In both studies cannabis users produced more errors of commission (failing to inhibit appropriately) than controls and also showed an altered pattern of brain activation. Eldreth et al. (2004) found that cannabis users showed relatively reduced left anterior cingulate, bilateral dorsolateral prefrontal cortex and right ventromedial prefrontal cortex activation but greater activation in the hippocampus bilaterally. Conversely, Gruber \& Yurgelun-Todd (2005) report that nine users showed greater activation relative to nine controls in the midcingulate cortex and right dorsolateral prefrontal cortex. Consistent with the former study (Eldreth et al. 2004), cannabis users showed reduced anterior cingulated activation. These results suggest that alterations of cingulate and prefrontal circuits occur in chronic cannabis users, and leads to the hypothesis that they recruit alternative brain networks as a compensatory mechanism.

Decision making. Bolla et al. (2005) report dysfunction in decision making and associated decreased cortical activation in 11 cannabis users, after 25 days of cannabis abstinence, compared with 11 non-users. Using ${ }^{15} \mathrm{OH}_{2} \mathrm{O}-\mathrm{PET}$ to study activation during the Iowa Gambling Task, they demonstrated that cannabis users not only had a poorer performance than controls but also showed less activation in the right orbitofrontal and dorsolateral prefrontal cortex and greater activation in the left parietal and cerebellar cortex. Within the cannabis user group, the number of joints smoked per week was also positively correlated with activation in the right parahippocampal gyrus but inversely correlated with activation in the right orbital gyrus and cerebellum (Bolla et al. 2005).

Motor performance. Pillay et al. (2004) reported decreased activation in the supplementary motor area and also in the ACC in nine cannabis users, $36 \mathrm{~h}$ after cessation of use, while they performed the finger sequencing task (a measure of fine motor function). No significant correlations between urinary cannabis level, verbal IQ, attention maintenance [the auditory
Continuous Performance Test (CPT)], reaction time, memory [the Buschke selective reminding test (BSRT)] and brain activation were found. On the contrary, Murphy et al. (2006) found no activation differences between 20 chronic cannabis users, after $24 \mathrm{~h}$ of cessation of use, and 25 healthy controls during a fingertapping task using fMRI. Both studies were methodologically well-designed and although the cannabis abstinence period was slightly shorter in the first study, these differences between them do not fully explain the divergent results.

\section{Discussion}

We found 41 studies suitable for inclusion. The results of this systematic review have indicated some of the methodological limitations of the work conducted to date and demonstrate the high level of heterogeneity in the findings of these studies. Some of the functional studies in the literature had groups that were smaller than what would be usually regarded as an acceptable minimum (for PET or SPECT studies 10 subjects and for fMRI studies 15 subjects). Therefore, studies involving larger samples and incorporating longitudinal designs may prove useful. The resting state studies conducted so far did not control spontaneous neural activity and modulation of the BOLD signal. The functional studies that used cognitive tasks explored different brain functions, making it difficult to confirm the results obtained. Thus there is a need for replication of these findings. Although the strict inclusion and exclusion criterion of the protocol is one of this review's strengths, it is possible that some of the excluded articles contain interesting pieces of cannabis research.

However, several relatively consistent findings emerged from this review. Functional neuroimaging studies suggest that resting global, prefrontal and ACC blood flow are lower in cannabis users than in controls (Mathew et al. 1986; Tunving et al. 1986; Block et al. 2000 b; Lundqvist et al. 2001; Sevy et al. 2008; Sneider et al. 2008). The localization of resting state differences between users and controls to these regions is broadly consistent with data from neuropsychological studies. Impairments in time estimation, attention, working memory, cognitive flexibility (Solowij et al. 2002), decision making (Bechara et al. 2001), and psychomotor speed (Bolla et al. 2002) in chronic cannabis users are, at least partly, mediated by these cortical regions. Evidence of effects of THC on activity in these areas is also consistent with the relatively high concentration of $\mathrm{CB}_{1}$ receptors in the prefrontal and cingulated cortex (Freund et al. 2003).

Functional imaging studies that compared activation in cannabis users and controls during cognitive 
tasks indicate that cannabis users make use of similar brain areas to controls while performing some cognitive tasks, although to a lesser degree (Block et al. 2002; Eldreth et al. 2004; Pillay et al. 2004; Bolla et al. 2005; Gruber \& Yurgelun-Todd, 2005; Jager et al. 2006, 2007). Moderately greater task-related activation in these areas may reflect impaired efficiency of processing following cannabis use, such that more activation is required to maintain normal performance. This is broadly consistent with the cognitive efficiency hypothesis (Vernon, 1983) that proposes that more direct connections between task-critical brain regions may correspond to decreases in task-related neural activity and improvements in performance (Rypma \& D'Esposito, 2000). The recruitment of additional regions, such as the prefrontal cortex and hippocampus, also differentiates users from controls during cognitive performance (Block et al. 2002; Eldreth et al. 2004; Gruber \& Yurgelun-Todd, 2005; Jager et al. 2007). This may indicate that increased neurocognitive resources are required to maintain memory and executive processes in this group. However, despite these differences in brain activity, the level of performance of the cannabis users was equivalent to that of controls (Kanayama et al. 2004; Jager et al. 2007). In this sense the brain seems to be capable of some degree of functional reorganization, activating brain regions not engaged in the non-users to achieve the cognitive demand. This interpretation implies that drug-related compensatory mechanisms may work, but the real impact of such alterations in daily users' life and its possibility to induce psychiatric disorders are still controversial.

With regard to structural neuroimaging studies, only two found significant differences between users and controls (Matochik et al. 2005; Yücel et al. 2008). It is likely that volumetric effects would only be observed in heavy long-term users whereas functional effects would be much easier to detect. Only one DTI study found differences in the mean diffusivity, suggesting that cannabis users have a small but significant effect on white matter structural integrity (Arnone et al. 2008).

Finally, more consistent results were evident in functional imaging studies that examined brain activity after the acute experimental administration of THC or marijuana cigarettes with THC. The most frequent finding was the increased resting prefrontal, insular and anterior cingulate activity (Volkow et al. 1996; Mathew et al. 1997, 1998, 1999, 2002). Studies that combined the administration of THC or marijuana with a cognitive task also described modulated activation in these regions (O'Leary et al. 2002, 2003, 2007; Borgwardt et al. 2008; Phan et al. 2008; Fusar-Poli et al. 2009). The acute administration of CBD has been associated with increased resting activity in the left parahippocampus gyrus and a reduction in medial temporal cortex activity while subjects were processing intensely fearful faces (Crippa et al. 2004). Of interest, two studies (Borgwardt et al. 2008; Fusar-Poli et al. 2009) showed, for the first time, different brain activation associated with THC and CBD in healthy volunteers, providing new insights into the pharmacodynamic effects.

\section{Acknowledgements}

This study was partly supported by the following grants: Psychiatric Research Grant: 2004/170 (UK); Plan Nacional Sobre Drogas: PNSD 2006/101(20072009) (Spain). J.A.C. and G.B.F. are recipients of a CNPq Productivity (2006-2009) fellowship (Brazil).

\section{Declaration of Interest}

None.

\section{References}

Aasly J, Storsaeter O, Nilsen G, Smevik O, Rinck P (1993). Minor structural brain changes in young drug abusers. A magnetic resonance study. Acta Neurologica Scandinavica 87, 210-214.

Amen DG, Waugh M (1998). High resolution brain SPECT imaging of marijuana smokers with $\mathrm{AD} / \mathrm{HD}$. Journal of Psychoactive Drugs 30, 209-214.

Arnone D, Barrick TR, Chengappa S, Mackay CE, Clark CA, Abou-Saleh MT (2008). Corpus callosum damage in heavy marijuana use: preliminary evidence from diffusion tensor tractography and tract-based spatial statistics. Neuroimage 41, 1067-1074.

Arseneault L, Cannon M, Witton J, Murray RM (2004). Causal association between cannabis and psychosis: examination of the evidence. British Journal of Psychiatry 184, 110-117.

Ashtari M, Cervellione K, Cottone J, Ardekani BA, Kumra S (2009). Diffusion abnormalities in adolescents and young adults with a history of heavy cannabis use. Journal of Psychiatric Research 43, 189-204.

Bechara A, Dolan S, Denburg N, Hindes A, Anderson SW, Nathan PE (2001). Decision-making deficits, linked to a dysfunctional ventromedial prefrontal cortex, revealed in alcohol and stimulant abusers. Neuropsychologia 39, 376-389.

Berger A, Posner MI (2000). Pathologies of brain attentional networks. Neuroscience and Biobehavioral Reviews 24, 3-5.

Block RI, O'Leary DS, Ehrhardt JC, Augustinack JC, Ghoneim MM, Arndt S, Hall JA (2000a). Effects of frequent marijuana use on brain tissue volume and composition. Neuroreport 11, 491-496.

Block RI, O'Leary DS, Hichwa RD, Augustinack JC, Boles Ponto LL, Ghoneim MM, Arndt S, Hurtig RR, Watkins 
GL, Hall JA, Nathan PE, Andreasen NC (2002). Effects of frequent marijuana use on memory-related regional cerebral blood flow. Pharmacology, Biochemistry, and Behavior 72, 237-250.

Block RI, O'Leary DS, Hichwa RD, Augustinack JC, Ponto LL, Ghoneim MM, Arndt S, Ehrhardt JC, Hurtig RR, Watkins GL, Hall JA, Nathan PE, Andreasen NC (2000b). Cerebellar hypoactivity in frequent marijuana users. Neuroreport 11, 749-753.

Bolla KI, Brown K, Eldreth D, Tate K, Cadet JL (2002). Dose-related neurocognitive effects of marijuana use. Neurology 59, 1337-1343.

Bolla KI, Eldreth DA, Matochik JA, Cadet JL (2005). Neural substrates of faulty decision-making in abstinent marijuana users. Neuroimage 26, 480-492.

Borgwardt SJ, Allen P, Bhattacharyya S, Fusar-Poli P, Crippa JA, Seal ML, Fraccaro V, Atakan Z, Martin-Santos R, O'Carroll C, Rubia K, McGuire PK (2008). Neural basis of $\Delta$-9-tetrahydrocannabinol (THC) and cannabidiol (CBD): effects during response inhibition. Biological Psychiatry 64, 966-973.

Bossong MG, van Berckel BN, Boellaard R, Zuurman L, Schuit RC, Windhorst AD, van Gerven JM, Ramsey NF, Lammertsma AA, Kahn RS (2009). Delta 9tetrahydrocannabinol induces dopamine release in the human striatum. Neuropsychopharmacology 34, 759-766.

Campbell AM, Evans M, Thomson JL, Williams MJ (1971). Cerebral atrophy in young cannabis smokers. Lancet 2, 1219-1224.

Chang L, Chronicle EP (2007). Functional imaging studies in cannabis users. Neuroscientist 13, 422-432.

Chang L, Yakupov R, Cloak C, Ernst T (2006). Marijuana use is associated with a reorganized visual-attention network and cerebellar hypoactivation. Brain 129, 1096-1112.

Co BT, Goodwin DW, Gado M, Mikhael M, Hill SY (1977). Absence of cerebral atrophy in chronic cannabis users. Evaluation by computerized transaxial tomography. Journal of the American Medical Association 237, 1229-1230.

Crippa JA, Lacerda AL, Amaro E, Busatto FG, Zuardi AW, Bressan RA (2005). Brain effects of cannabis neuroimaging findings [in Portuguese]. Revista Brasileira de Psiquiatria 27, 70-78.

Crippa JA, Zuardi AW, Garrido GE, Wichert-Ana L, Guarnieri R, Ferrari L, Azevedo-Marques PM, Hallack JE, McGuire PK, Filho Busatto G (2004). Effects of cannabidiol (CBD) on regional cerebral blood flow. Neuropsychopharmacology 29, 417-426.

DeLisi LE (2008). The effect of cannabis on the brain: can it cause brain anomalies that lead to increased risk for schizophrenia? Current Opinion in Psychiatry 21, 140-150.

DeLisi LE, Bertisch HC, Szulc KU, Majcher M, Brown K, Bappal A, Ardekani BA (2006). A preliminary DTI study showing no brain structural change associated with adolescent cannabis use. Harm Reduction Journal 3, 17.

Eldreth DA, Matochik JA, Cadet JL, Bolla KI (2004). Abnormal brain activity in prefrontal brain regions in abstinent marijuana users. Neuroimage 23, 914-920.

Freund TF, Katona I, Piomelli D (2003). Role of endogenous cannabinoids in synaptic signaling. Physiological Reviews 83, 1017-1066.
Fusar-Poli P, Crippa JA, Bhattacharyya S, Borgwardt SJ, Allen P, Martin-Santos R, Seal M, Surguladze SA, O'Carrol C, Atakan Z, Zuardi AW, McGuire PK (2009). Distinct effects of (delta)9-tetrahydrocannabinol and cannabidiol on neural activation during emotional processing. Archives of General Psychiatry 66, 95-105.

Gonzalez R (2007). Acute and non-acute effects of cannabis on brain functioning and neuropsychological performance. Neuropsychology Review 17, 347-361.

Gorelick DA, Heishman SJ (2006). Methods for clinical research involving cannabis administration. Methods in Molecular Medicine 123, 235-253.

Gruber SA, Yurgelun-Todd DA (2005). Neuroimaging of marijuana smokers during inhibitory processing: a pilot investigation. Brain Research. Cognitive Brain Research 23, 107-118.

Hall W, Solowij N (1998). Adverse effects of cannabis. Lancet 352, 1611-1616.

Hannerz J, Hindmarsh T (1983). Neurological and neuroradiological examination of chronic cannabis smokers. Annals of Neurology 13, 207-210.

Hermann D, Sartorius A, Welzel H, Walter S, Skopp G, Ende G, Mann K (2007). Dorsolateral prefrontal cortex $\mathrm{N}$-acetylaspartate/total creatine (NAA/tCr) loss in male recreational cannabis users. Biological Psychiatry 61, 1281-1289.

Hirst RA, Lambert DG, Notcutt WG (1998). Pharmacology and potential therapeutic uses of cannabis. British Journal of Anaesthesia 81, 77-84.

Hollister LE (1986). Health aspects of cannabis. Pharmacological Reviews 38, 1-20.

Jacobsen LK, Mencl WE, Westerveld M, Pugh KR (2004). Impact of cannabis use on brain function in adolescents. Annals of the New York Academy of Sciences 1021, 384-390.

Jacobsen LK, Pugh KR, Constable RT, Westerveld M, Mencl WE (2007). Functional correlates of verbal memory deficits emerging during nicotine withdrawal in abstinent adolescent cannabis users. Biological Psychiatry 61, 31-40.

Jager G, Kahn RS, Van Den Brink W, Van Ree JM, Ramsey NF (2006). Long-term effects of frequent cannabis use on working memory and attention: an fMRI study. Psychopharmacology (Berlin) 185, 358-368.

Jager G, Van Hell HH, De Win MM, Kahn RS, Van Den Brink W, Van Ree JM, Ramsey NF (2007). Effects of frequent cannabis use on hippocampal activity during an associative memory task. Journal of the European College of Neuropsychopharmacology 17, 289-297.

Kanayama G, Rogowska J, Pope HG, Gruber SA, Yurgelun-Todd DA (2004). Spatial working memory in heavy cannabis users: a functional magnetic resonance imaging study. Psychopharmacology (Berlin) 176, 239-247.

Kuehnle J, Mendelson JH, Davis KR, New PF (1977). Computed tomographic examination of heavy marijuana smokers. Journal of the American Medical Association 237, 1231-1232.

Li CS, Milivojevic V, Constable RT, Sinha R (2005). Recent cannabis abuse decreased stress-induced BOLD signals in the frontal and cingulate cortices of cocaine dependent individuals. Psychiatry Research 140, 271-280. 
Lundqvist T (2005). Cognitive consequences of cannabis use: comparison with abuse of stimulants and heroin with regard to attention, memory and executive functions. Pharmacology, Biochemistry, and Behavior 81, 319-330.

Lundqvist T, Jonsson S, Warkentin S (2001). Frontal lobe dysfunction in long-term cannabis users. Neurotoxicology and Teratology 23, 437-443.

Mathew RJ, Tant S, Burger C (1986). Regional cerebral blood flow in marijuana smokers. British Journal of Addiction 81, 567-571.

Mathew RJ, Wilson WH (1993). Acute changes in cerebral blood flow after smoking marijuana. Life Sciences 52, 757-767.

Mathew RJ, Wilson WH, Chiu NY, Turkington TG, DeGrado TR, Coleman RE (1999). Regional cerebral blood flow and depersonalization after tetrahydrocannabinol administration. Acta Psychiatrica Scandinavica 100, 67-75

Mathew RJ, Wilson WH, Coleman RE, Turkington TG, DeGrado TR (1997). Marijuana intoxication and brain activation in marijuana smokers. Life Sciences 60, 2075-2089.

Mathew RJ, Wilson WH, Humphreys DF, Lowe JV, Wiethe KE (1992a). Regional cerebral blood flow after marijuana smoking. Journal of Cerebral Blood Flow and Metabolism 12, 750-758.

Mathew RJ, Wilson WH, Humphreys DF, Lowe JV, Wiethe KE (1992b). Changes in middle cerebral artery velocity after marijuana. Biological Psychiatry 32, 164-169.

Mathew RJ, Wilson WH, Tant SR (1989). Acute changes in cerebral blood flow associated with marijuana smoking. Acta Psychiatrica Scandinavica 79, 118-128.

Mathew RJ, Wilson WH, Turkington TG, Coleman RE (1998). Cerebellar activity and disturbed time sense after THC. Brain Research 797, 183-189.

Mathew RJ, Wilson WH, Turkington TG, Hawk TC, Coleman RE, DeGrado TR, Provenzale J (2002). Time course of tetrahydrocannabinol-induced changes in regional cerebral blood flow measured with positron emission tomography. Psychiatry Research 116, 173-185.

Matochik JA, Eldreth DA, Cadet JL, Bolla KI (2005). Altered brain tissue composition in heavy marijuana users. Drug and Alcohol Dependence 77, 23-30.

Murphy K, Dixon V, LaGrave K, Kaufman J, Risinger R, Bloom A, Garavan H (2006). A validation of event-related FMRI comparisons between users of cocaine, nicotine, or cannabis and control subjects. American Journal of Psychiatry 163, 1245-1251.

Nestor L, Roberts G, Garavan H, Hester R (2008). Deficits in learning and memory: parahippocampal hyperactivity and frontocortical hypoactivity in cannabis users. Neuroimage 40, 1328-1339.

O'Leary DS, Block RI, Flaum M, Schultz SK, Boles Ponto LL, Watkins GL, Hurtig RR, Andreasen NC, Hichwa RD (2000). Acute marijuana effects on rCBF and cognition: a PET study. Neuroreport 11, 3835-3841.

O'Leary DS, Block RI, Koeppel JA, Flaum M, Schultz SK, Andreasen NC, Ponto LB, Watkins GL, Hurtig RR, Hichwa RD (2002). Effects of smoking marijuana on brain perfusion and cognition. Neuropsychopharmacology 26, 802-816.
O'Leary D, Block RI, Koeppel JA, Schultz SK, Magnotta VA, Boles Ponto L, Watkins FL, Hichwa RD (2007). Effects of smoking marijuana on focal attention and brain flow. Human Psychopharmacology 22, 135-148.

O'Leary DS, Block RI, Turner BM, Koeppel J, Magnotta VA, Ponto LB, Watkins GL, Hichwa RD, Andreasen NC (2003). Marijuana alters the human cerebellar clock. Neuroreport 14, 1145-1151.

Pertwee RG, Ross RA (2002). Cannabinoid receptors and their ligands. Prostaglandins, Leukotrienes and Essential Fatty Acids 66, 101-121.

Phan KL, Angstadt M, Golden J, Onyewuenyi I, Popovska A, de Wit H (2008). Cannabinoid modulation of amygdala reactivity to social signals of threat in humans. Journal of Neuroscience 28, 2313-2319.

Pillay SS, Rogowska J, Kanayama G, Jon DI, Gruber S, Simpson N, Cherayil M, Pope HG, Yurgelun-Todd DA (2004). Neurophysiology of motor function following cannabis discontinuation in chronic cannabis smokers: an fMRI study. Drug and Alcohol Dependence 76, 261-271.

Quickfall J, Crockford D (2006). Brain neuroimaging in cannabis use: a review. Journal of Neuropsychiatry and Clinical Neuroscience 18, 318-332.

Ranganathan M, D'Souza DC (2006). The acute effects of cannabinoids on memory in humans: a review. Psychopharmacology (Berlin) 188, 425-444.

Roser P, Vollenweider FX, Kawohl W (2008). Potential antipsychotic properties of central cannabinoid (CB(1)) receptor antagonists. World Journal of Biological Psychiatry 7, $1-12$.

Rypma B, D’Esposito M (2000). Isolating the neural mechanisms of age-related changes in human working memory. Nature Neuroscience 3, 509-515.

Schneider M (2008). Puberty as a highly vulnerable development period for the consequences of cannabis exposure. Addiction Biology 13, 253-263.

Schweinsburg AD, Schweinsburg BC, Cheung EH, Brown GG, Brown SA, Tapert SF (2005). fMRI response to spatial working memory in adolescents with comorbid marijuana and alcohol use disorders. Drug and Alcohol Dependence 79, 201-210.

Sevy S, Smith GS, Ma Y, Dhawan V, Chaly T, Kingsley PB, Kumra S, Abdelmessih S, Eidelberg D (2008). Cerebral glucose metabolism and D2/D3 receptor availability in young adults with cannabis dependence measured with positron emission tomography. Psychopharmacology (Berlin) 197, 549-556.

Sneider JT, Pope Jr. HG, Silveri MM, Simpson NS, Gruber SA, Yurgelun-Todd DA (2006). Altered regional blood volume in chronic cannabis smokers. Experimental and Clinical Psychopharmacology 14, 422-428.

Sneider JT, Pope Jr. HG, Silveri MM, Simpson NS, Gruber SA, Yurgelun-Todd DA (2008). Differences in regional blood volume during a 28-day period of abstinence in chronic cannabis smokers. European Neuropsychopharmacology 18, 612-619.

Solowij N, Stephens RS, Roffman RA, Babor T, Kadden R, Miller M, Christiansen K, McRee B, Vendetti J (2002). Cognitive functioning of long-term heavy cannabis users 
seeking treatment. Journal of the American Medical Association 287, 1123-1131.

Tunving K, Thulin SO, Risberg J, Warkentin S (1986). Regional cerebral blood flow in long-term heavy cannabis use. Psychiatry Research 17, 15-21.

Tzilos GK, Cintron CB, Wood JB, Simpson NS, Young AD, Pope Jr. HG, Yurgelun-Todd DA (2005). Lack of hippocampal volume change in long-term heavy cannabis users. American Journal on Addictions 14, 64-72.

Vernon PA (1983). Speed of information processing and general intelligence. Intelligence 7, 53-70.

Volkow ND, Fowler JS, Wang GJ (2003). The addicted human brain: insights from imaging studies. Journal of Clinical Investigation 111, 1444-1451.

Volkow ND, Gillespie H, Mullani N, Tancredi L, Grant C, Ivanovic M, Hollister L (1991). Cerebellar metabolic activation by delta-9-tetrahydro-cannabinol in human brain: a study with positron emission tomography and 18F-2-fluoro-2-deoxyglucose. Psychiatry Research 40, 69-78.

Volkow ND, Gillespie H, Mullani N, Tancredi L, Grant C, Valentine A, Hollister L (1996). Brain glucose metabolism in chronic marijuana users at baseline and during marijuana intoxication. Psychiatry Research 67, 29-38.

Voruganti LN, Slomka P, Zabel P, Mattar A, Awad AG (2001). Cannabis induced dopamine release: an in-vivo SPECT study. Psychiatry Research 107, 173-177.

Voytek B, Berman SM, Hassid BD, Simon SL, Mandelkern MA, Brody AL, Monterosso J, Ling W, London ED (2005). Differences in regional brain metabolism associated with marijuana abuse in methamphetamine abusers. Synapse 57, 113-115.

Ward PB, Solowij N, Peters R, Otton J, Chesher G, Grenyer B (2002). An fMRI study of regional brain volumes in long-term cannabis users. Journal of Psychopharmacology 16 (Suppl. 3), A56.

Watson SJ, Benson Jr. JA, Joy JE (2000). Marijuana and medicine: assessing the science base: a summary of the
1999 Institute of Medicine report. Archives of General Psychiatry 57, 547-552.

Weinstein A, Brickner O, Lerman $H$, Greemland $M$, Bloch M, Lester H, Chisin R, Mechoulam R, Bar-Hamburger R, Freedman N, Even-Sapir E (2008). Brain imaging study of the acute effects of Delta9-tetrahydrocannabinol (THC) on attention and motor coordination in regular users of marijuana. Psychopharmacology (Berlin) 196, 119-131.

Wiesbeck GA, Taeschner KL (1991). A cerebral computed tomography study of patients with drug-induced psychoses. European Archives of Psychiatry and Clinical Neuroscience 241, 88-90.

Williamson EM, Evans FJ (2000). Cannabinoids in clinical practice. Drugs 60, 1303-1314.

Wilson W, Mathew R, Turkington T, Hawk T, Coleman RE, Provenzale J (2000). Brain morphological changes and early marijuana use: a magnetic resonance and positron emission tomography study. Journal of Addictive Diseases 19, $1-22$.

Yücel M, Solowij N, Respondek C, Whittle S, Fornito A, Pantelis C, Lubman DI (2008). Regional brain abnormalities associated with long-term heavy cannabis use. Archives of General Psychiatry 65, 694-701.

Yurgelun-Todd DA, Gruber SA, Hanson RA, Baird AA, Renshaw PF, Pope HG (1998). Residual effects of marijuana use: an fMRI study. In Problems of drug dependence. Proceedings of the 60th Annual Scientific Meeting. The College on Problems of Drug Dependence (ed. L. S. Harris). NIDA Research Monograph 179, 78 .

Zuardi AW (2006). History of cannabis as a medicine: a review. Revista Brasileira de Psiquiatria 28, 153-157.

Zuardi AW, Shirakawa I, Finkelfarb E, Karniol IG (1982). Action of cannabidiol on the anxiety and others effects produced by delta 9-THC in normal subjects. Psychopharmacology (Berlin) 76, 245-250. 